\title{
HUBUNGAN TEKSTUR SEDIMEN DENGAN MANGROVE DI DESA MOJO KECAMATAN ULUJAMI KABUPATEN PEMALANG
}

\author{
Correlation of Sediment Textureand Mangrove at Mojo Village SubdistrictUlujamiPemalang
}

\section{Hida Rizki Aini, Agung Suryanto, Boedi Hendrarto}

Program Studi Manajemen Sumberdaya Perairan, Jurusan Perikanan

Fakultas Perikanan dan Ilmu Kelautan, Universitas Diponegoro

Jl. Prof. Soedarto, SH, Tembalang, Semarang, Jawa Tengah - 50275, Telp/Fax. +6224 7474698

Email : hidarizkiaini@gmail.com

\begin{abstract}
ABSTRAK
Desa Mojo merupakan salah satu wilayah Kecamatan Ulujami yang memiliki kawasan mangrove yang luas. Hutan mangrove di Desa Mojo merupakan hasil rehabilitasi yang dilakukan oleh masyarakat sekitar dan pihak terkait. Hutan mangrove Desa Mojo mempunyai fungsi yang sangat penting bagi daerah sekitarnya. Rehabilitasi yang telah dilakukan tersebut memberikan efek terhadap ekosistem. Habitat mangrove yang ada di Desa Mojo tersebut kemungkinan memberikan karakteristik terhadap sedimen sebaliknya karakteristik sedimen merupakan faktor penting terhadap keberadaan mangrove. Penelitian dilakukan pada bulan Maret - april 2016. Tujuan penelitian ini adalah untuk mengetahui hubungan karakteristik sedimen terhadap tegakan mangrove. Metode yang digunakan untuk menghitung kerapatan mangrove yaitu Point Centered Quarter Method. Karakteristik sedimen meliputi pengukuran fisika sedimen, pengukuran tekstur sedimen dengan metode Soil Jar Test (FAO), dan bahan organik sedimen diukur dengan metode LOI (Loss on Ignition). Hasil penelitian menunjukkan bahwa kondisi kawasan mangrove di Desa Mojo termasuk sangat padat, karena memiliki kerapatan lebih dari 1500 pohon per hektar (KepMenLH No.201, 2004). Sedimen pada kawasan mangrove Desa Mojo memiliki karakteristik tekstur silt (lumpur). Hasil Principal Component Analysis korelasi spesies mangrove dipengaruhi langsung oleh kuantitas silt dibandingkan dengan faktor lingkungan lainnya.
\end{abstract}

Kata Kunci : Tekstur sedimen; Mangrove; Ulujami; Pemalang

\section{ABSTRACT}

Mojo village is one of the District of Ulujamithat has extensive mangrove areas. The mangrove forest in the village of Mojo is the result of the rehabilitation undertaken by the local community and other interested parties. It has a very important function for the surrounding area. The rehabilitation has been done to give effect to the ecosystem. Mangrove habitat in the village of Mojo and sediment characteristics of mutrual influenced.. The study was conducted in March - April 2016. The purpose of this study was to determine the correlation characteristic of sediment to mangrove stands. The method used to calculate the density of mangrove namely Point Centered Quarter Method. Sediment characteristics include physical measurements of sediment, sediment texture measurement method Jar Test Soil (FAO), and sedimentary organic matter is measured by the method of LOI (Loss on Ignition). The results showed that the condition of the mangrove area in the village of Mojo include very dense, because it has a density of more than 1500 trees per hectare (KepMenLH 201, 2004). Sediment in the mangrove areas Desa Mojo has the characteristic texture of silt. The data used by the Principal Component Analysis correlation mangrove species were influenced by the quantity of silt, while there is no direct impact on other environmental factors on the existing mangrove species.

Keywords: Sediment texture,Mangrove. Ulujami, Pemalang

\section{PENDAhuluan}

Desa Mojo merupakan wilayah yang teletak di pantai utara Pulau Jawa di Kabupaten Pemalang yang merupakan daerah potensial untuk tumbuhnya mangrove. Hutan mangrove merupakan ekosistem peralihan antara daratan dan lautan, pertumbuhannya dipengaruhi oleh adanya sedimen dan faktor lingkungan lainnya. Salah satu faktor yang mendukung komposisi mangrove yang baik yaitu sedimen. Karakteristik sedimen yang baik menentukan pertumbuhan mangrove.

Karakteristik sedimen merupakan faktor pembatas terhadap pertumbuhan mangrove. Tekstur dan konsentrasi ion mempunyai susunan jenis dan kerapatan tegakan Misalnya jika komposisi sedimen lebih banyak liat (clay) dan lumpur (silt) maka tegakan menjadi lebih rapat. Sedimen mangrove memiliki kekhasan secara

\footnotetext{
${ }^{\circledR}$ Copyright by Management of Aquatic Resources (MAQUARES)
} 
alami. Sedimen mangrove dapat dijadikan sebagai patokan untuk melihat potensi dan produktivitasnya. Dataran estuarin ditumbuhi oleh mangrove karena ada sinergis (timbal balik), satu sisi tumbuhan mampu tumbuh lebat, agresif, cepat menyebar, tetapi disisi lain dengan akarnya (rapat, tenunan akar) dapat menangkap sedimen (lumpur) sehingga terjadi endapan. Kondisi ini menjadikan pemantapan pertumbuhan dan pengembangan daratan (Rusmendro, 2008).Komposisi spesies dan pertumbuhan mangrove tergantung pada komposisi fisik dari sedimen. Proporsi dari ukuran partikel pasir, debu dan liat mempengaruhi permeabilitas sedimen, kesuburan dan salinitas sedimen(English et al., 1994).

Tujuan dilakukannya penelitian ini adalah (1) mengetahui kondisi kerapatan mangrove Desa Mojo; (2) mengetahui karakteristik sedimen pada komunitas mangrove Desa Mojo; (3) mengetahui hubungan antara komunitas mangrove dengan karakteristik sedimen.

\section{MATERI DAN METODE PENELITIAN}

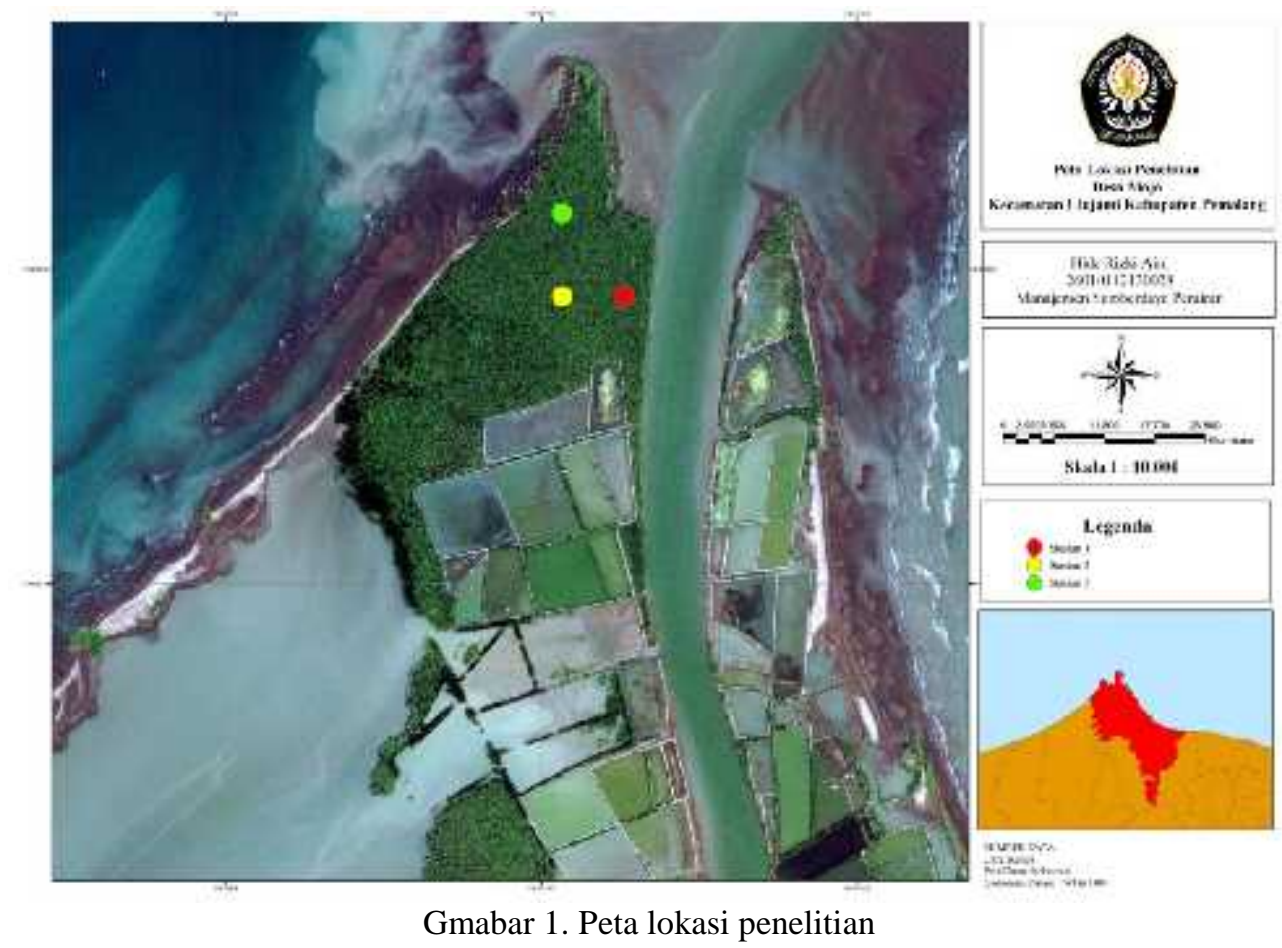

Penelitian ini dilakukan di Hutan Mangrove Desa Mojo, Kecamatan Ulujami, Kabupaten Pemalang. Desa Mojo termasuk dalam wilayah yang merupakan daerah pesisir pantai yang dilalui sungai comal, kawasan mangrove di daerah ini terdapat di pesisir pantai desa Mojo yaitu pada ujung muara sungai comal. Sampling lapangan dilakukan di 3 stasiun. Stasiun 1 berada dekat dengan muara sungai comal, stasiun 2 berada di tengah hutan mangrove, stasiun 3 berada dekat dengan pantai. Tegakan mangrove yang diukur mencakup diameter setinggi dada pada batang dan jarak pohon terdekat dengan titik sampling yang diukur dengan menggunakan rol meter.Pengukuran vegetasi mangrove dilakukan menggunakan metode titik pusat kuadran (point centered quarter method) menurut Cottam dan Curtis(1956), yaitu merupakan salah satu metode jarakdengan menggunakan sejumlah titik yang disebarkan secara teratur pada suatu garis transek, setiap transek yang satu dengan yang lainnya mempunyai jarak yang sama. Pada titik pengambilan contoh dibuat dua buah garis yang tegak lurus satu dengan lainnya sehingga terdapat 4 buat kuadran. Pada setiap kuadran, jarak antara titik pengambilan contoh dengan pohon terdekat diukur. Pengukuran dimensi pohon meliputi basal area dan jenis pohon hanya dilakukan terhadap keempat pohon terdekat yang dipilih . Pengukuran vegetasi mangrove dihitung menggunakan rumus berikut :

$$
\begin{array}{ll}
\text { Kerapatan relatif } & =\frac{\text { individu spesies }}{\text { total individu semuaspesies }} \times 100 \% \\
\text { Dominasi relatif } & =\frac{\text { total bagal area spesies }}{\text { total basalarsa semua spesies }} \times 100 \% \\
\text { Frekuensi realtif } & =\frac{\text { Total titik kehadiranspesies }}{\text { Total seluruh titiksampel semus spesits }} \times 100 \% \\
\text { Basal area } & =\left(\frac{\text { Diameter }}{2}\right)^{2} \times 3,14 \\
\text { INP } & =\text { Kerapatan relatif + Dommasurelatit + Frehuensi relatit }
\end{array}
$$

\footnotetext{
${ }^{\circledR}$ Copyright by Management of Aquatic Resources (MAQUARES)
} 
Sampel sedimen diambil pada setiap titik di 3 stasiun berdasarkan vegetasi mangrove yang dianggap rapat, sedang dan jarang. Pengambilan sedimen dilakukan dengan menarik garis transek dengan menggunakan roll meter sepanjang $50 \mathrm{~m}$ di setiap stasiun, pada setiap stasiun terdapat 5 titik dengan jarak antar titik yaitu 10 m. Permukaan tempat sedimen yang akan diambil dibersihkan terlebih dahulu. Sedimen tersebut diambil dengan menggunakan pipa paralon pada kedalaman $15 \mathrm{~cm}$. Sedimen yang telah diambil dimasukkan ke dalam kantong sampel dan dicatat lokasi stasiunnya. Pengukuran salinitas dan $\mathrm{pH}$ sedimen mangrove dilakukan dengan mengambil beberapa sampel sedimen pada titik yang telah ditentukan. Sampel sedimen tersebut dimasukkan ke dalam spot suntik yang bagian bawahnya telah diberi kertas saring / kapas, kemudian ditekan hingga keluar kandungan air dari sedimen tersebut. Air dari sedimen tersebut ditempatkan pada refraktometer dan kertas $\mathrm{pH}$, kemudian dibaca dan dicatat skala yang terlihat (Kushartono, 2004).

\section{Pengukuran tekstur sedimen}

Metode yang digunakan dalam analisa tekstur sedimen menggunakan metode Soil Jar Test (FAO) yaitu dengan menggunakan gelas ukur berukuran $500 \mathrm{ml}$ sebagai pengganti jar kosong dengan penutup. Gelas ukur diisi dengan setengah penuh sedimen kemudian diberi air hampir penuh. Gelas ukur ditutup menggunakan plastik press, kemudian dikocok beberapa menit hingga tercampur. Diamkan gelas ukur hingga endapan terlihat selama sehari.

\section{Pengukuran bahan organik}

Metode yang digunakandalamanalisisbahan organik sedimen adalah menggunakan metode LOI (Loss on Ignition) menurut Heiri et al., (2001), yaitu sedimen seberat 5 gram ditempatkan pada cawan porselen sebagai wadah, kemudian dikeringkan dengan oven bersuhu tinggi $\left(550^{\circ} \mathrm{C}\right)$ selama 5 jam. Kadar bahan organik dihitung dengan rumus:

$$
\begin{aligned}
& \text { BUI }=\frac{(W t-C)-(W a-C)}{W t-C} \times 100 \\
& \text { Keterangan : } \\
& \text { BOT }=\text { Bahan Organik Total } \\
& \mathrm{Wt}=\text { Berat total crucible dan sampel sebelum dibakar } \\
& \mathrm{C} \quad=\text { Berat crucible kosong } \\
& \mathrm{Wa} \quad=\text { Berat total crucible dan sampel setelah dibakar }
\end{aligned}
$$

\section{Analisis data}

Analisis data yang digunakan untuk mengetahui korelasi dari karakteristik antar jenis mangrove berdasarkan variabel - variabel lingkungannya serta kemiripan antar stasiun berdasarkan indek nilai penting dan variebel lingkungnnya sehingga digunakan Principal component analysis (PCA) dan analisis clustering.

\section{HASIL DAN PEMBAHASAN}

Hasil

Desa Mojo termasuk dalam wilayah yang merupakan daerah pesisir pantai yang dilalui sungai comal, kawasan mangrove di daerah ini terdapat di pesisir pantai desa Mojo yaitu pada ujung muara sungai comal serta di area pertambakan. Tanaman mangrove yang ada pada lokasi penelitian ditanam dengan tujuan agar dapat menahan gempuran ombak dan juga terjadinya abrasi, karena dibelakang daerah mangrove terdapat tambak milik penduduk. Namun seiring dengan perkembangan waktu daerah ini dikembangkan untuk tujuan wisata.Spesies mangrove yang mendominasi ditemukan di lokasi penelitian terdiri dari R. mucronata, A. alba, dan A. marina. Mangrove yang berada di lokasi tersebut umumnya telah mencapai ukuran pohon.

Deskripsi terhadap vegetasi mangrove di Desa Mojo dijelaskan dengan data Indeks nilai penting (INP).

a. Indeks nilai penting (INP)

Hasil pengukuran Indeks nilai penting mangrove Desa Mojo tersaji pada Tabel 6.

Tabel 6. Indeks nilai penting mangrove Desa Mojo

\begin{tabular}{llccc}
\hline \multirow{2}{*}{ No. } & \multirow{2}{*}{ Spesies Mangrove } & \multicolumn{3}{c}{ Indeks Nilai Penting (\%) } \\
\cline { 3 - 5 } & & Stasiun I & Stasiun II & Stasiun III \\
\hline 1. & Rhizophora mucronata & 168,42 & 138,79 & 136,03 \\
2. & Avicennia alba & 84,65 & 47,31 & 51,58 \\
3. & Avicennia marina & 46,93 & 113,90 & 112,39 \\
\hline & Jumlah & 300 & 300 & 300 \\
\hline
\end{tabular}

Hasil perhitungan indeks nilai penting (INP) dari tiga spesies mangrove yang diperoleh pada tiga stasiun di lokasi penelitian didapatkan indeks nilai penting spesies tertinggi pada ketiga stasiun yaitu spesies $R$. mucronata. 


\section{b. Bahan organik}

Hasil pengukuran bahan organik sedimen tersaji padaTtabel 7.

Tabel 7. Hasil pengukuran kandungan bahan organik sedimen (\%)

\begin{tabular}{llll}
\hline & Stasiun 1 & Stasiun 2 & Stasiun 3 \\
\hline Titik 1 & 20,12 & 13,05 & 13,22 \\
Titik 2 & 16,76 & 19,2 & 22,04 \\
Titik 3 & 19,6 & 21,3 & 20,08 \\
Titik 4 & 19,04 & 20,9 & 21,5 \\
Titik 5 & 20,80 & 12,22 & 20,56 \\
\hline Rerata \pm SD & $19,26 \pm 1,54$ & $17,33 \pm 4,37$ & $19,48 \pm 3,58$ \\
\hline
\end{tabular}

Hasil yang didapat pada pengukuran bahan organik di ketiga stasiun memiliki nilai yang bervariasi pada setiap titik sampling pada setiap stasiun. Hasil perhitungan rata - rata nilai bahan organik tertinggi yaitu pada stasiun 3.

\section{c. Fisika sedimen}

Hasil pengukuran bahan organik sedimen tersaji pada Tabel 8 .

Tabel 8. Pengukuran variabel suhu, $\mathrm{pH}$, dan salinitas sedimen

\begin{tabular}{|c|c|c|c|c|c|c|c|}
\hline & & Titik 1 & Titik 2 & Titik 3 & Titik 4 & Titik 5 & Rerata \pm SD \\
\hline \multirow[t]{3}{*}{ Stasiun 1} & Suhu $\left({ }^{\circ} \mathrm{C}\right)$ & 29 & 29 & 29 & 29 & 29 & $29 \pm 0$ \\
\hline & $\mathrm{pH}$ & 6 & 6 & 6 & 6 & 6 & $6 \pm 0$ \\
\hline & Salinitas $(\%$ ) & 6 & 7 & 10 & 18 & 20 & $12,2 \pm 6,42$ \\
\hline \multirow[t]{3}{*}{ Stasiun 2} & Suhu $\left({ }^{\circ} \mathrm{C}\right)$ & 28 & 28 & 28 & 29 & 29 & $28,4 \pm 0,55$ \\
\hline & $\mathrm{pH}$ & 7 & 7 & 7 & 7 & 7 & $7 \pm 0$ \\
\hline & Salinitas $(\%$ ) & 21 & 15 & 20 & 24 & 27 & $21.4 \pm 4,51$ \\
\hline \multirow[t]{3}{*}{ Stasiun 3} & Suhu $\left({ }^{\circ} \mathrm{C}\right)$ & 29 & 29 & 29 & 29 & 29 & $29 \pm 0$ \\
\hline & $\mathrm{pH}$ & 7 & 7 & 7 & 7 & 7 & $7 \pm 0$ \\
\hline & Salinitas $(\%$ oo & 18 & 20 & 24 & 25 & 30 & $23,4 \pm 4,67$ \\
\hline
\end{tabular}

Hasil pengukuran terhadap fisika sedimen pada lokasi penelitian di hutan mangrove Desa Mojo, didapatkan hasil pengukuran terhadap suhu sedimen dan $\mathrm{pH}$ sedimen pada setiap stasiun konstan, sedangkan salinitas sedimen memiliki nilai yang bervariasi pada setiap stasiun.

\section{d. Analisis tekstur sedimen}

Hasil pengukuran analisis tekstur sedimen tersaji pada Tabel 10.

Tabel 10. analisis tekstur sedimen

\begin{tabular}{llllllll}
\hline & & Titik 1 & Titik 2 & Titik 3 & Titik 4 & Titik 5 & Rerata \pm SD \\
\hline Stasiun 1 & Clay (\%) & 5,06 & 2,44 & 10 & 4,29 & 2,11 & $4,78 \pm 3,17$ \\
& Silt $(\%)$ & 94,94 & 97,56 & 90 & 95,71 & 97,89 & $95,22 \pm 3,17$ \\
& Warna & Abu & Abu & Abu & Abu & Abu & Abu \\
& Tekstur & Lumpur & Lumpur & Lumpur & Lumpur & Lumpur & Lumpur \\
\hline Stasiun 2 & Clay (\%) & 1,5 & 1,25 & 1,82 & 1,91 & 1,81 & $1,66 \pm 0,28$ \\
& Silt $(\%)$ & 98,5 & 98,75 & 98,18 & 98,19 & 98,19 & $98,36 \pm 0,26$ \\
& Warna & Abu & Abu & Abu & Abu & Abu & Abu \\
& Tekstur & Lumpur & Lumpur & Lumpur & Lumpur & Lumpur & Lumpur \\
\hline Stasiun 3 & Clay (\%) & 1,15 & 2,61 & 2,2 & 3,95 & 3,1 & $2,06 \pm 1,04$ \\
& Silt $(\%)$ & 98,85 & 97,39 & 97,8 & 96,05 & 96,9 & $97,4 \pm 1,04$ \\
& Warna & Abu & Abu & Abu & Abu & Abu & Abu \\
& Tekstur & Lumpur & Lumpur & Lumpur & Lumpur & Lumpur & Lumpur \\
\hline
\end{tabular}

Hasil pengukuran yang dilakukan terhadap tekstur sedimen dengan menggunakan metode soil jar test, pada lokasi penelitian dengan kedalaman pengambilan $15 \mathrm{~cm}$ berdasarkan pengamatan terhadap pengendapan sedimen yaitu silt (lumpur)dan clay (liat).Karakteristik tekstur sedimen pada stasiun 1,2 dan 3 didominasi oleh silt. Sedangkan warna sedimen pada ketiga stasiun tidak ada perbedaan yaitu abu. 


\section{e. Analisis PCA}

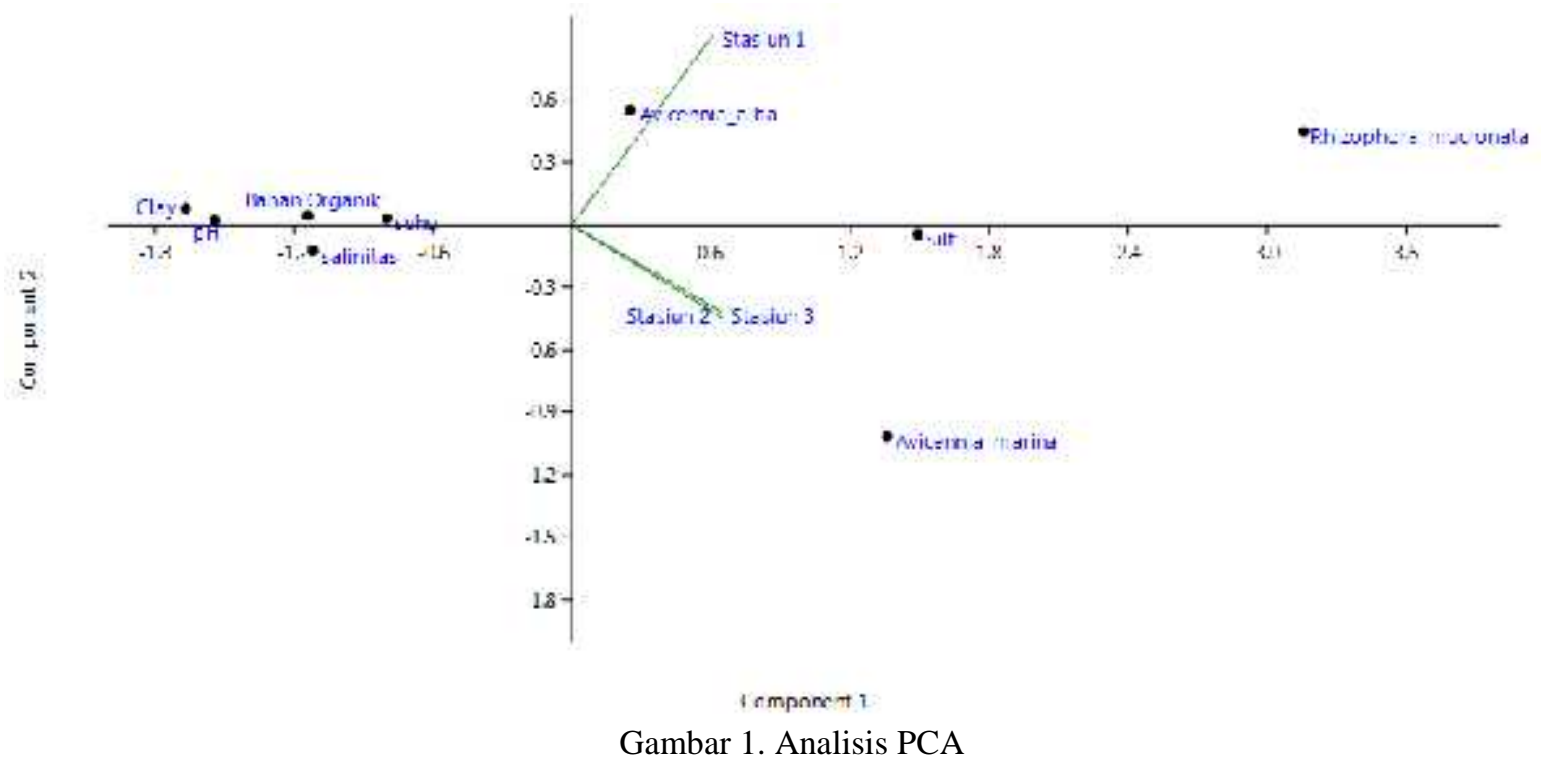

Pembahasan

Kawasan mangrove desa Mojo Kecamatan Ulujami Kabupaten Pemalang memiliki potensi besar untuk tempat tumbuhnya tumbuhan mangrove. Mangrove yang berada di daerah tersebut didominasi oleh mangrove $R$. mucronata, kemudian A. alba dan A. marina. Menurut penelitian terdahulu oleh Syawala (2013), R. mucronata lebih dominan daripada A. marina karena memang hanya bibit $R$. mucronata yang ditanam oleh masyarakat dengan kerja sama dengan Oisca-Tokio Marine. $R$. mucronata menjadi bibit rehabilitasi hutan mengrove di Pantai Mojo karena awalnya daerah ini merupakan daerah pertambakan dimana kawasan hutan mangrove yang sekarang merupakan hasil penanaman kembali.

Kerapatan mangrove terbesar berada pada stasiun 2 yaitu 3066 pohon per hektar, kemudian stasiun 1 sebesar 2772 pohon per hektar, dan stasiun 3 sebesar 1997 pohon per hektar.Berdasarkan keputusan Menteri Lingkungan Hidup No. 201, tahun 2004 perhitungan kerapatan yang diperoleh pada ketiga stasiun di lokasi penelitian tergolong dalam kriteria sangat padat, dikatakan sangat padat apabila memiliki kerapatan lebih dari atau sama dengan 1500 pohon/hektar.Berdasarkan hasil perhitungan bahan organik sedimen didapatkan nilai bahan organik yang bervariasi pada setiap stasiun. Dimana nilai bahan organik tertinggi berada pada stasiun 3 yang mempunyai kerapatan paling rendah yaitu 1997 pohon/ha yaitu dengan nilai rata - rata bahan organik sebesar $19,48 \%$. Rata - rata nilai bahan organik tertinggi kedua berada pada stasiun 1 dengan kerapatan 2772 pohon/ha yaitu sebesar 19,26\%. Kemudian rata - rata nilai bahan organik terendah berada pada stasiun 2 dengan kerapatan 3066 pohon / ha yaitu sebsar 17,33\%. Hal ini dapat menunjukkan bahwa kerapatan yang tinggi tidak berpengaruh terhadap tingginya kandungan bahan organik. Menurut Darmadi (2012), di Desa Cangkringan, Indramayu, hasil penelitian menunjukkan bahwa kerapatan mangrove tinggi pada tingkat pancang dan semai di stasiun I memiliki kandungan bahan organik yang cenderung rendah hingga sangat rendah, hal ini dikarenakan bahan organik tersebut digunakan atau diambil oleh akar untuk pertumbuhan mangrove. Hasil rata - rata bahan organik pada ketiga stasiun tersebut menunjukakan bahwa kandungan bahan organik pada lokasi penelitian masuk dalam kriteria tinggi. Tingginya nilai kandungan bahan organik tersebut dapat disebabkan oleh karakteristik tekstur sedimen pada lokasi penelitian yang memiliki tekstur lumpur. Menurut Reynolds dalam Kushartono (2004), Kriteria bahan organik tinggi yaitu antara 17 - $35 \%$. Bahan organik terdapat pada lapisan tanah bagian atas atau permukaan. Tumbuh-tumbuhan dan aktivitas sejumlah besar organisme terjadi pada permukaan tanah bagian atas.

Hasil pengukuran analisis tekstur sedimen yang dilakukan pada kedalaman sedimen $15 \mathrm{~cm}$ di lokasi penelitian pada stasiun 1, 2, dan 3 tidak jauh berbeda yaitu didapatkan tekstur debu di ketiga stasiun. Berdasarkan analisa tekstur tanah yang dilakukan di laboratorium dengan menggunakan soil jar test didapatkan kandungan silt (lumpur) lebih tinggi dibandingkan dengan clay (liat), sedangkan kandungan pasir tidak ada. Tekstur sedimen yaitu silt dapat disebabkan karena letak lokasi kawasan mangrove yang yang tidak langsung dekat dengan pantai yang memiliki arus dan gelombang tinggi. Hal ini dipengaruhi oleh vegetasi mangrove pada lokasi penelitian yang padat sehingga dapat menyebabkan produksi serasah tinggi dan kemampuan akar mangrove tersebut dalam mengikat lumpur. Hal tersebut sesuai dengan yang dikemukakan oleh Mahmud (2014), jenis tanah yang mendominasi kawasan mangrove biasanya fraksi lempung berdebu sebagai akibat rapat perakaran mangrove yang ada. Menurut Setiawan (2013), berdasarkan penelitian yang dilakukan, lokasi dengan tingkat ketebalan mangrove tinggi memiliki tekstur tanah lempung liat berdebu. Pada lokasi dengan ketebalan 
mangrove sedang yaitu liat berdebu sedangkan lokasi tanpa vegetasi mangrove memiliki tekstur pasir sehingga keberadaan vegetasi mangrove sangat berpengaruh terhadap pembentukan klas tekstur tanah. Pada daerah dengan tingkat ketebalan mangrove yang tinggi cenderung mempunyai klas tekstur lempung liat berdebu, hal ini disebabkan karena adanya dekomposisi serasah yang ikut menentukan klas tekstur tanah dan adanya pengikatan partikel debu dan liat oleh akar vegetasi mangrove sehingga lama-kelamaan partikel tersebut akan mengendap dan membentuk lumpur.

Berdasarkan hasil pengukuran variabel fisika sedimen, suhu sedimen pada stasiun 1,2 dan 3 sangat stabil dengan nilai berkisar antara $28-29{ }^{\circ} \mathrm{C}$. Hal ini disebabkan karena usia dari tanaman mangrove sudah dewasa dan tinggi sehingga menutupi hampir seluruh permukaan tanah.Menurut English, et al., (1997) dalam Agustin (2013), kebanyakan pH tanah pada hutan mangrove berada pada kisaran $6-7$, meskipun ada beberapa yang nilai $\mathrm{pH}$ tanahnya dibawah 5.Salinitas yang diperoleh memiliki nilai yang bervariasi, pada stasiun 1 salinitas berkisar antara $6-20 \%$, pada stasiun 2 salinitas antara $15-27 \%$, dan pada stasiun 3 nilai salinitas antara $18-30 \%$. Perbedaan nilai salinitas yang bervariasi ini disebabkan oleh lokasi stasiun yang berbeda, dimana stasiun 1 berada dekat dengan muara sungai comal, stasiun 2 berada di tengah kawasan konservasi mangrove dan stasiun 3 lokasinya berada dekat dengan pantai. Menurut penelitian yang dilakukan Kushartono (2004), kenaikan konsentrasi salinitas dipengaruhi oleh air yang masuk kedalam tanah yang berasal dari intrusi air laut yang datang pada saat pasang surut dimana air laut tersebut meresap kebawah dan sampai pada lapisan kedap air, kemudian berkumpul sehingga salinitasnya lebih tinggi. Menurut Kathiresan (2001), mangrove sejati (misalnya, Avicennia spp. dan Rhizophora spp.) mentolerir salinitas yang lebih tinggi daripada non-hutan bakau, tapi toleransi juga bervariasi antara jenis bakau sejati.

Berdasarkan hasil analisa dengan menggunakan Principal component analysis (PCA) untuk mengetahui korelasi spesies mangrove antara $R$. mucronata, A. alba, dan A. marina dengan variabel lingkungan yang diukur maka didapatkan grafik yang telah tersaji pada gambar 4 . Pada grafik pemetaan tersebut $R$. mucronata dan $A$. alba memiliki korelasi dengan variabel bahan organik, suhu, $\mathrm{pH}$ dan unsur clay / liat pada sedimen. Dimana sifat korelasi $R$. mucronata dan A. alba dengan bahan organik, suhu, pH, unsur clay (liat) adalah positif. Sedangkan A. marina memiliki sifat korelasi positif terhadap salinitas dan silt, dimana keberadaan spesies mangrove $A$. marina pada lokasi penelitian diduga dipengeruhi oleh salinitas, dan unsur silt pada sedimen. Menurut Hutahaean (1999), jenis mangrove A. marina memiliki pertumbuhan daun yang optimal pada salinitas berkisar antara 22,5 - 30 ppt. Menurut Joshi (2003), di Lothian Pulau Sundarbans Barat A. marina mendominasi dimana lokasi tersebut memiliki nilai salinitas lebih. A. marina memiliki kemampuan hidup yang optimal pada salinitas 18,4 dan 20,9 ppt. Adanya unsur silt yang mempengaruhi yaitu A. marina mampu tumbuh pada keadaan lumpur yang tinggi atau keberadaannya tergantung dari adanya lumpur pada sedimen. Hasil analisis data dengan Principal component analysis (PCA), menunjukkan bahwa tekstur sedimen silt berpengaruh langsung terhadap jenis mangrove $R$. mucronata, Avicennia alba dan A. marina yang ada di hutan mangrove Desa Mojo. Menurut Panapitukkul et al. (1998) dalam Duarte et al.(1998), beban lumpur yang tinggi dapat bermanfaat untuk kemajuan mangrove. Beban lumpur yang tinggi di sungai menyebabkan peningkatan pertambahan sedimen dan dengan demikian pembentukan habitat baru yang cocok untuk kolonisasi bakau alam dan perkembangan berkelanjutan hutan mangrove yang luas. Hasil penelitian Duarte et al.(1998), menunjukkan bahwa peningkatan pengendapan lumpur akan meningkatkan pertumbuhan bibit, yang kemungkinan membantu bibit untuk mempunyai berat yg lebih besar dari tingkat kematian tinggi yang dihadapi oleh bibit yang tidak dilindungi yang baru ditanam.

\section{KESIMPULAN}

Kesimpulan yang diperoleh pada penelitian mengenai Karakteristik Sedimen pada Tegakan Mangrove di Desa Mojo, Kecamatan Ulujami Kabupaten pemalang sebagai berikut :

1. Kondisi kawasan mangrove di Desa Mojo termasuk sangat padat, karena memiliki kerapatan lebih dari 1500 pohon per hektar.

2. Karakteristik sedimen pada hutan mangrove Desa Mojo didominasi oleh karakteristik tekstur silt.

3. HasilPrincipal Component Analysis(PCA) korelasi spesies mangrove $R$. mucronata, A. alba dan A. marina dipengaruhi langsung oleh tekstur sedimen silt sedangkan parameter lingkungan yang lain tidak berpengaruh langsung terhadap spesies mangrove yang ada.

\section{UCAPAN TERIMA KASIH}

Ucapan terima kasih ditujukan kepada Ir. Siti Rudiyanti, M.Si, Dr. Ir. Pujiono Wahyu Purnomo, M.S., Dr.Ir. Bambang Sulardiono, M.Sidan Churun Ain, S.Pi, M.Siyang telah banyak memberikan masukan kepada penulis dalam penulisan makalah ini. 


\section{DAFTAR PUSTAKA}

Agustin, Y.L., M. Muryono, dan H. Purnobasuki. 2012. Estimasi Stok karbon pada Tegakan Pohon Rhizophora stylosa di Pantai Talang Iring, Pamekasan Madura. Institut Teknologi Sepuluh Nopember.

Cottam, G., dan J.T. Curtis. 1965. The Use of Distance Measures in Phytosociological Sampling. Ecology. 37 (3) $: 451-460$.

Darmadi, M.W. Lewaru, dan A.M.A. Khan 2012. Struktur Komunitas Vegetasi Mangrove Berdasarkan Karakteristik Substrat di Muara Harmin Desa Cangkring Kecamatan Cantigi Kabupaten Indramayu. 3 (2) :347 - 358

Duarte, C.M., O.G. Hansen, and Udomluck, T. 1998. Relationship between sediment conditions and Mangrove Rhizophora apiculata Seedling growth and Nutrient stastus. Mar Ecol Prog Ser., 175 : 277 - 283.

English S., C.Wilkinson and V.Baker. 1994. Survey Manual for Tropical Marine Resources. Townsville (AU). Australian Institute of Marine Science.

FAO. 2016. Soil Texture. ftp://ftp.fao.org/fi/cdrom/fao_training/FAO_Training/General/x6706e/x6706e06.htm (28 Februari 2016).

Hamdi, Asep Saepul. 2014. Metode Penelitian Kuantitatif Aplikasi dalam Pendidikan. DEEPUBLISH. Yogyakarta

Heiri, O., A. F. Lotter, and G. Lemcke. 2001. Loss On Ignation as A Method For Estimating Organic and Carbonate Content in Sediments: Reproducibility and Comparability of Results. Journal of Paleolimnology. 25: $101-110$.

Hutahaean, E.E., C. Kusuma, dan H.R. Dewi. 1999. Studi Kemampuan Tumbuh Anakan Mangrove Jenis Rhizophora mucronata, Bruguiera gimnorrhiza dan Avicennia marina Pada Berbagai Tingkat Salinitas. Jurnal Manajemen Hutan Tropika, V (1) : 77.

Joshi, H. Dan M. Ghose. 2003. Forest structure and Species Distribution along Soil Salinity and pH gradient in Mangrove Swamps of The Sundarbans. Tropical Ecology. 44 (2) : 197 - 206.

Kathiresan, K. dan B.L. Bingham. 2001. Biology of Mangroves and Mangrove Ecosystems. Advances in marine biology. $40: 81$ - 251. Annamalai University. Parangipettai.

Keputusan Menteri Negara Lingkungan Hidup Nomor : 201. 2004. Kriteria Baku dan Pedoman Penentuan Kerusakan Mangrove. Deputi MENLH Bidang Kebijakan dan Kelembagaan Lingkungan Hidup : Jakarta.

Kushartono, E.W. 2004. Beberapa Asepek Bio - Fisik - Kimia Tanah di Daerah Hutan Mangrove Desa Pasar Banggi Kabupaten Rembang. Tesis. Universitas Diponegoro. Semarang.

Mahmud, Wardah, dan B. Toknok. 2014. Sifat Fisik Tanah di Bawah Tegakan Mangrove di Desa Tumpapa Kecamatan Balinggi Kabupaten Parigi Moutong. Jurnal Warta Rimba. 2 (1) : 129 - 135.

Rusmendro, H. 2008. Watak dan Sifat Tanah Areal Rehabilitasi Mangrove Tabjung Pasir, Tangerang. 1(1) : 1 5.

Setiawan, H. 2013. Status Ekologi Hutan Mangrove pada Berbagai Tingkat Ketebalan. 2 (2) : $104-120$.

Syawala, N. 2013. Komposisi Vegetasi Hutan Mangrove di Pantai Mojo Kecamatan Ulujami Kabupaten Pemalang. Skripsi. Universitas Muhammadiyah Surakarta. 